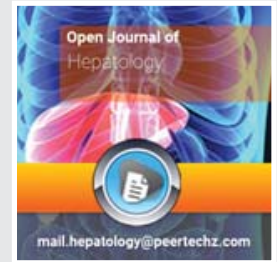

\section{Evaluation of association of} demographic profiles and sero prevalence of $\mathrm{HBV}$ and $\mathrm{HCV}$ among the patients presenting with chronic liver disease and its complications: A Tertiary Care Hospital Based Study

\author{
Richmond Ronald Gomes ${ }^{1 *}$ and Md. Akmat Ali ${ }^{2}$ \\ ${ }^{1}$ Associate Professor of Medicine, Ad-din Women's Medical College and Hospital, Dhaka, Bangladesh \\ ${ }^{2}$ Associate Professor of Hepatology, Ad-din Women's Medical College and Hospital, Dhaka, \\ Bangladesh
}

Received: 12 June, 2020

Accepted: 09 September, 2020

Published: 10 September, 2020

*Corresponding authors: Dr. Richmond Ronald Gomes, Associate Professor of Medicine, Ad-din Women's Medical College and Hospital, Dhaka, Bangladesh, Tel: 8801819289499; E-mail: rrichi.dmc.k56@gmail.com Keywords: Chronic liver disease; HBsAg; Anti HCV; ICT

https://www.peertechz.com

\section{Check for updates}

\title{
Abstract
}

Background: Now-a-days chronic liver disease is one of the major health problems in the world. In developing countries, chronic liver disease due to hepatitis virus (like hepatitis $\mathrm{B}$ and hepatitis $\mathrm{C}$ virus) is increasing day by day. It is rapidly emerging as a major health problem. So the present study was conducted to document the hepatitis B and hepatitis $C$ virus in patient with chronic liver disease by an easy and simple marker like HBsAg, Anti HBc (total) and Anti HCV in a tertiary hospital.

Methods: Serum samples were collected from 100 selected cases who were diagnosed as a case of chronic liver disease in medicine and gastroenterology department of DMCH. Study period was from April 01, 2016 to September 30, 2018. For detection of HBsAg, Anti HBc (total) and Anti HCV, Immunochromatographic Test (ICT) was done in every case.

Results: Out of 100 cases, HBsAg seropositive with negative Anti HCV was found in $64 \%$ cases, Anti HCV positive with negative HBsAg was found in $16 \%$ cases, both HBsAg and anti HCV positive was found in $4 \%$ cases, both HBsAg and anti HCV negative was found in $16 \%$ cases. Among these cases, $74 \%$ were male and $26 \%$ were female. Here male: female was 3:1 and among them, 75\% male was seropositive for either HBsAg or Anti HCV.

Conclusion: The high frequency of seropositivity in patients with chronic liver disease with male predominance is found in tertiary care settings. The number of Anti $\mathrm{HCV}$ seropositive patient indicates that it is an emerging health problem in our country.

\section{Introduction}

Chronic liver disease is one of the common hepatobiliary problems worldwide. A major portion of the cases of chronic liver disease presents as a sequel of hepatotrophic viral infection specially hepatitis B and hepatitis C virus. Hepatitis B virus infects more than 350 million people worldwide and it is a leading cause of chronic hepatitis, cirrhosis and hepatocellular carcinoma [1]. On the other hand hepatitis $C$ virus infects an estimated 170 million people worldwide and it represents a viral pandemic and mostly causes chronic infection leading to cirrhosis in $15-20 \%$ of those [2]. In Bangladesh the prevalence of chronic viral hepatitis $[3,4]$ is quite significant. It has been observed that a large number of people in Bangladesh suffer 
from viral hepatitis every year. Around $10-15 \%$ of patients are treated for liver diseases including hepatitis and their sequelae [5-9] in medical units in hospitals of Dhaka city. Hepatitis B virus infection is the major cause of mortality and morbidity related to chronic liver disease and also hepatitis $\mathrm{C}$ virus is emerging as another major health problem $[3,4]$. The patients with chronic liver disease in our hospital usually come with overt clinical manifestations and complications. In our country vast majority of cases are non alcoholic post viral sequelae is the most important cause. Among the etiologically implicated hepatotrophic viruses, hepatitis B virus has been reported most important and hepatitis $C$ virus related especially to chronic infection [9-12]. Clinically persistent presences of HBsAg and/ or Anti- HCV are correlated with chronic liver disease [9-13]. Most of the patients of chronic liver disease are likely to be the carrier of these viruses and hence persistent viraemia resulting in positive HBsAg and/ or Anti-HCV [14-16]. so they are potential source of Hepatitis B (HBV) and hepatitis C (HCV) virus infection for others. This study yet not has been done in our hospitals settings. This study is therefore undertaken to show the pictures of two common and cost effective viral markers like HBsAg and Anti-HCV(for hepatitis B and hepatitis $C$ virus infection respectively) in patients with chronic liver disease and their demographic profile, clinical presentation, complication profile and other related findings. The study will try to evaluate demographic profiles of those patients having post viral (HBV \& HCV) CLD in our settings.

\section{Materials and methods}

This observational, descriptive, longitudinal study was carried out on Medicine units and department of Gastroenterology of Dhaka Medical College Hospital from April, 2016 to September 2018. Total 100 cases, age between 15 to 75 years, including known cases of chronic liver disease with or without complications were selected. Diagnosis was made by analysis of clinical, biochemical, endoscopy of upper GIT and USG of whole abdomen findings. Histopathological examination was done in some selected cases. Collected data's were analyzed with the computer software SPSS.

Inclusion criteria: All cases (including known cases) of chronic liver disease with or without complications will be selected. Diagnosis will be made by analysis of clinical, biochemical and imaging features including evidences of varices on upper GI endoscopy. Histopathological examination will be done in some selected cases. Initial criteria's for selection of cases as chronic liver disease are:

\section{* Age between 15 to 75 years, and}

* Presence of stigmata of chronic liver disease( e.g. spider naevi, palmer erythema, gynaecomastia, testicular atrophy), and/or

* Cases having jaundice for more than 6 months, and/or

Clinical and laboratory evidences of portal hypertension.

\section{Exclusion criteria:}

\footnotetext{
* Age $<15$ years or $>75$ years
}

* The patient with chronic liver disease with known etiology other than hepatotrophic virus (Wilson's disease, drug induced, hemochromatosis, autoimmune hepatitis etc).

* The patients who will refuse to give consent

* The patient who will leave hospital before diagnosis

* Pregnant ladies

Following investigations will be done in all cases to support the diagnosis

* CBC, $\mathrm{PBF}$

* LFT's: S. bilirubin, ALT, ALP, STP, S. Albumin, A:G, PT

* USG of Whole Abdomen

* Upper GIT endoscopy

* Tests for viral markers: HBsAg, Anti HBc (total), AntiHCV.

* Alfa- Feto protein for suspected HCC

\section{Results}

A total number of 110 patients were screened and they were diagnosed as a case of Chronic Liver Disease (CLD). Among them 10 were excluded from the study. Among the excluded cases, 4 were absconded, 2 were dead before satisfactory diagnosis, 3 refused to give consent and 1 was known case of Wilson's disease. Total 100 cases were selected. Observational findings of this study are shown in different frequency tables and charts.

\section{Discussion}

In Bangladesh, Chronic parenchymal liver disease (CLD) is a common hepatobiliary problem. Chronic hepatitis $\mathrm{B}$ virus (HBV) and hepatitis $\mathrm{C}$ virus (HCV) infection are regarded as the most important cause of chronic liver disease in Bangladesh $[3,6,7]$. A substantial number of hospital admitted CLD patients are likely to be chronic carriers of HBV and HCV. A common serologic marker of HBV infection is HBsAg and HCV infection is Anti-HCV. After first identification of HBsAg by Blumberg, et al. [17], it has been widely used to identify chronic carriers of HBV. The HCV was discovered in 1989 and Anti-HCV antibodies were identified soon after the virus was discovered, and current iterations of these assays enable past exposure to HCV to be determined with high degree of accuracy $[1,2,5]$. Therefore, these patients constitute a major medical health hazards for medical personnel as well as for other patients by acting as a potential source of $\mathrm{HBV}$ and $\mathrm{HCV}$ infection. The present study was undertaken to find out the seroprevalence of HBsAg and Anti-HCV among the patients with CLD in DMCH with their demographic pattern, clinicopathological presentation, complication profile and the correlation of these features.

I have screened 110 consecutive patients who were admitted in medicine and gastroenterology units of Dhaka Medical 
College Hospital. Among them, 10 were excluded from the study. Among the excluded cases, 4 were absconded, 2 were dead before satisfactory diagnosis, 3 refused to give consent and 1 was known case of Wilson's disease. Total numbers of 100 cases were selected and ages of all were 15 years or more. Clinical history of the patients with their particulars (age, sex, occupation, socioeconomic condition, marital status(, relevant past history ( past $\mathrm{H} / \mathrm{O}$ jaundice, hospitalization, hematemesis \& melaena, altered or loss of consciousness, alcohol history, transfusion history, H/O injectable drug use) were carefully noted. The diagnostic parameters like biochemical, serological, ultrasonographic and endoscopic study were available in 100 percent cases; in addition histopathological examination was available in $28 \%$ of cases. Although ideally all the cases should have been studied by biopsy, but different contraindications (huge ascites, prolonged PT), logistic and financial difficulties and patients refusal precluded histopathological study in all cases.

However, strict attention to clinical and pathological details and other important investigations (like liver function tests including PT, USG of whole abdomen, endoscopy of upper GIT done in all cases) considerable compensated the lack of histopathological evidence. Among the 100 cases, in hospital settings, most of them are in decompensated stage or with complications which indicate compensated CLD are usually not come to our hospital for further management. Among the 100 cases, HBsAg seropositive with negative Anti-HCV in $64 \%$ cases, Anti-HCV positive with negative HBsAg in $16 \%$ cases, both HBsAg and Anti-HCV positive in $4 \%$ cases and both HBsAg and Anti-HCV negative in $16 \%$ cases (Table 1). So, still HBsAg seropositive group has higher prevalence among the patients with CLD and several number of Anti-HCV seropositive cases indicate that chronic liver disease as a result of HCV infection is not uncommon. Co-infection should be also considered in case of chronic liver disease.

Table 1: Seroprevalence of HBsAg and Anti-HCV in patients with chronic liver disease (CLD) $(n=100)$.

\begin{tabular}{|c|c|c|}
\hline Name of viral marker with status & Total & Percentage (\%) \\
\hline HBsAg positive but Anti-HCV negative & 64 & 64 \\
\hline Anti HCV positive but HBsAg negative & 16 & 16 \\
\hline Both HBsAg and Anti-HCV positive & 4 & 4 \\
\hline Both HBsAg and Anti-HCV negative & 16 & 16 \\
\hline
\end{tabular}

Different previous reports from Bangladesh showed a wide range $(30-62.5 \%)$ of HBsAg seropositivity in CLD patients $[8,18,19,20]$. NaherDaulatun, Bishwas Jolly, et al. showed $65.9 \%$ HBsAg positive in patients of CLD in a hospital of Bangladesh which is almost similar to this study findings [3]. Khan M, Kiyosawa K, Yano M, et al. showed $24.1 \%$ seropositive for Anti-HCV in patients with CLD in Bangladesh which is almost similar to this study findings report [4] $(16+8=24 \%)$. Chakravarti A, Verma V. Prevalence of hepatitis B and hepatitis $\mathrm{C}$ viral markers in patients with chronic liver disease: A study from Northern India showed HBV infection in $60.6 \%$ cases \& it was detected by using all three markers. Among them,
HBsAg was positive in $33.3 \%$ cases. Similar findings were reported by other workers but it was lower than this study. HCV infection was present in $25.75 \%$ patients with CLD which is similar to my study [16]. $79.41 \%$ of total HCV infected cases showed co infection with HBV (past or present infection) [16]. Here co infection was detected by various markers but in this study we had done only one marker that might be the cause of having HBsAg with Anti-HCV positive in $4 \%$ cases. The high prevalence of HBsAg among the patients with CLD is not surprising if we consider that the HBsAg prevalence amongst the general population of Bangladesh which is between 7.8 to 8.6 percent [12]. But prevalence of CLD due to HCV infection is not less now a days [12].

High incidence of HBsAg seropositiviry in the patients with CLD ranging from 25 to $60 \%$ had been reported from Iraq [21], greece [22], Africa [23] \&India [24]. All of these countries have high HBsAg seroprevalence amongst the general population $[22,24]$. Such association however was rarely observed in patients with CLD in Australia [25] and Great Britain [26]. This is consistent with their very low (0.1-0.2\%) HBsAg seroprevalence amongst general population. Another study was done in Myanmar and khin PyoneKy, Myo Aye, et al. showed Anti-HCV positive in $38.5 \%$ cases of cirrhosis, in $29.3 \%$ cases of HCC. Although general population showed 2.5\% Anti HCV positive [22].

The age and sex (Tables 2,3) distribution in the present study were similar to other reports $[7,8,20,27-29]$. Here $75 \%$ patients were male and $25 \%$ were female with a male to female ratio 3:1. This male preponderance in this hospital based study corresponds to previous studies [6-8,27-29] and perhaps reflects social prejudice, male are in high risk of transmission of hepatitis virus and avoidance of hospital admission by females. The study showed more male patients than female were admitted/came to this hospital with a feature of CLD. Among those, males are higher seropositive for HBsAg ( $75 \%)$, Anti-HCV ( $75 \%$ and both $(100 \%)$ which is consistent with another previous study [30]. D Naher, et al. showed 75.3\% male and $24.7 \%$ female were HBsAg positive among the cases of CLD [3]. Taher Selim Khan, et al. showed 73.3\% male and $26.7 \%$ female were Anti-HCV positive in Pakistan [15], which is similar to my study.

In my study, age incidence showed young and middle age group of patients were much higher seropositive for HBsAg and Anti-HCV. In 20-50 years group, HBsAg were positive in $68.75 \%$ and Anti-HCV positive in $62.5 \%$. $37.5 \%$ cases were found Anti-HCV positive in age group more than 51 years. Similar findings had shown in another previous study [15]. Myanmar and KhinPyoneKy, Myo Aye, et al. showed that the prevalence of Anti-HCV positive cases were more in older age group [31].

The occupational status in patient with CLD (Table 4) showed that the people of various occupations were an unfortunate victim of CLD. Among the CLD cases, $26 \%$ were businessman, $24 \%$ were service holder. Among the HBsAg positive cases, $25 \%$ were service holder and $21,87 \%$ were businessman. Among the Anti-HCV positive cases, $50 \%$ were 
businessman. NaherDaulatun, Bishwas Jolly, et al. showed $47.2 \%$ were service holder which was a bit higher than my study (Their study was done in different hospitals) [3]. This is similar to findings of Sobur [27], Chowdhury [19], Datta [28], Parveen [29] and Rahman's [32] studies.

Socioeconomic background analysis (Table 5) showed that most of the patients came from middle economic class (64\%) or poor economic class (32\%) and only $4 \%$ came from upper economic class. So, in our hospital setting, the patient of various economic classes especially the poor and the middle economic class came with the features of CLD. Among the cases of both seronegative group, $70 \%$ cases were in middle economic class. This is similar to the findings of Nahar Daulatun, Bishwas Jolly, et al. [3] study.

\section{Conclusion}

Chronic Liver Disease (CLD) is common in tertiary care hospital setting. Hepatitis B (HBV) and Hepatitis C (HCV) virus are important causes of chronic liver disease (CLD). Hepatitis

Table 2: Seroprevalence of HBsAg and Anti-HCV in patients of chronic liver disease (CLD) with their age distribution $(n=100)$.

\begin{tabular}{|c|c|c|c|c|c|}
\hline $\begin{array}{c}\text { Age in } \\
\text { years }\end{array}$ & $\begin{array}{c}\text { HbsAg positive } \\
\text { but Anti-HCV } \\
\text { negative } \\
\mathbf{n = 6 4 ( \% )}\end{array}$ & $\begin{array}{c}\text { Anti- HCV } \\
\text { positive but } \\
\text { HbsAg negative } \\
\mathbf{n = 1 6 ( \% )}\end{array}$ & $\begin{array}{c}\text { Both HbsAg } \\
\text { and Anti-HCV } \\
\text { positive } \\
\mathbf{n = 4 ( \% )}\end{array}$ & $\begin{array}{c}\text { Both HbsAg } \\
\text { and Anti-HCV } \\
\text { negative } \\
\mathbf{n = 1 6}(\%)\end{array}$ & $\begin{array}{c}\text { Total: } \\
\mathbf{n}= \\
\mathbf{1 0 0}(\%)\end{array}$ \\
\hline$<20$ & $6(9.38 \%)$ & $0(0 \%)$ & $0(0 \%)$ & $0(0 \%)$ & 6 \\
\hline $21-30$ & $6(9.38 \%)$ & $2(12.5 \%)$ & $0(0 \%)$ & $2(12.5 \%)$ & 10 \\
\hline $31-40$ & $22(34.38 \%)$ & $4(25 \%)$ & $0(0 \%)$ & $2(12.5 \%)$ & 28 \\
\hline $41-50$ & $16(25 \%)$ & $4(25 \%)$ & $4(100 \%)$ & $8(50 \%)$ & 32 \\
\hline $51-60$ & $10(15.63 \%)$ & $6(37.5 \%)$ & $0(0 \%)$ & $2(12.5 \%)$ & 18 \\
\hline$>60$ & $4(6.25 \%)$ & $0(0 \%)$ & $0(0 \%)$ & $2(12.5 \%)$ & 6 \\
\hline
\end{tabular}

Table 3: Seroprevalence of HBsAg and Anti-HCV in patients with chronic liver disease (CLD) with their sex distribution $(n=100)$.

\begin{tabular}{|c|c|c|}
\hline Name of the viral marker & Male & Female \\
\hline HbsAg positive but Anti HCV negative, $\mathrm{n}=64(\%)$ & $48(75 \%)$ & $16(25 \%)$ \\
\hline Anti- HCV positive but HbsAg negative, $\mathrm{n}=16(\%)$ & $12(75 \%)$ & $4(25 \%)$ \\
\hline Both HbsAg and Anti HCV positive, $\mathrm{n}=4(\%)$ & $4(100 \%)$ & $0(0 \%)$ \\
\hline Both HbsAg and Anti HCV negative, $\mathrm{n}=16(\%)$ & $10(62.5 \%)$ & $6(37.5 \%)$ \\
\hline Total: $\mathrm{n}=100(\%)$ & $74 \%$ & $26 \%$ \\
\hline
\end{tabular}

Table 4: Seroprevalence of $\mathrm{HbsAg}$ and $\mathrm{Anti} \mathrm{HCV}$ in patients with chronic liver disease (CLD) with their occupational status $(n=100)$.

\begin{tabular}{|c|c|c|c|c|c|}
\hline $\begin{array}{c}\text { Name of the } \\
\text { occupation }\end{array}$ & $\begin{array}{c}\text { HbsAg positive } \\
\text { but Anti-HCV } \\
\text { negative } \\
\mathbf{n = 6 4}(\%)\end{array}$ & $\begin{array}{c}\text { Anti- HCV } \\
\text { positive } \\
\text { but HbsAg } \\
\text { negative } \\
\mathbf{n = 1 6}(\%)\end{array}$ & $\begin{array}{c}\text { Both HbsAg } \\
\text { and Anti-HCV } \\
\text { positive } \\
\mathbf{n = 4} \mathbf{4}(\%)\end{array}$ & $\begin{array}{c}\text { Both HbsAg } \\
\text { and Anti-HCV } \\
\text { negative } \\
\mathbf{n = 1 6}(\%)\end{array}$ & $\begin{array}{c}\text { Total: } \\
\mathbf{n =} \\
\mathbf{1 0 0}(\%)\end{array}$ \\
\hline Housewife & $12(18.75 \%)$ & $4(25 \%)$ & $0(0 \%)$ & $4(25 \%)$ & 20 \\
\hline Student & $8(12.5 \%)$ & $0(0 \%)$ & $0(0 \%)$ & $2(12.5 \%)$ & 10 \\
\hline Laborer & $12(18.75 \%)$ & $0(0 \%)$ & $0(0 \%)$ & $2(12.5 \%)$ & 14 \\
\hline $\begin{array}{c}\text { Service } \\
\text { holder }\end{array}$ & $16(25 \%)$ & $4(25 \%)$ & $0(0 \%)$ & $4(25 \%)$ & 24 \\
\hline Businessman & $14(21.87 \%)$ & $8(50 \%)$ & $2(50 \%)$ & $2(12.5 \%)$ & 26 \\
\hline Others & $2(3.13 \%)$ & $0(0 \%)$ & $2(50 \%)$ & $2(12.5 \%)$ & 6 \\
\hline
\end{tabular}

Table 5: Seroprevalence of HbsAg and Anti HCV in patients with chronic liver disease (CLD) with their economic status $(n=100)$.

\begin{tabular}{|c|c|c|c|c|c|}
\hline $\begin{array}{c}\text { Economic } \\
\text { status }\end{array}$ & $\begin{array}{c}\text { HbsAg positive } \\
\text { but Anti-HCV } \\
\text { negative } \\
\mathbf{n = 6 4}(\%)\end{array}$ & $\begin{array}{c}\text { Anti- HCV } \\
\text { positive } \\
\text { but HbsAg } \\
\text { negative } \\
\mathbf{n = 1 6}(\%)\end{array}$ & $\begin{array}{c}\text { Both HbsAg } \\
\text { and Anti-HCV } \\
\text { positive } \\
\mathbf{n = 4} \mathbf{4}(\%)\end{array}$ & $\begin{array}{c}\text { Both HbsAg } \\
\text { and Anti-HCV } \\
\text { negative } \\
\mathbf{n = 1 6}(\%)\end{array}$ & $\begin{array}{c}\text { Total: } \\
\mathbf{n}= \\
\mathbf{1 0 0}(\%)\end{array}$ \\
\hline $\begin{array}{c}\text { Poor class }< \\
4000 \text { taka/ } \\
\text { month }\end{array}$ & $22(34.38 \%)$ & $4(25 \%)$ & $2(50 \%)$ & $4(25 \%)$ & 32 \\
\hline $\begin{array}{c}\text { Middle class } \\
4000-10000 \\
\text { taka/month }\end{array}$ & $38(59.38 \%)$ & $12(75 \%)$ & $2(50 \%)$ & $12(75 \%)$ & 64 \\
\hline $\begin{array}{c}\text { Higher class } \\
>10000 \text { taka/ } \\
\text { month }\end{array}$ & $4(6.25 \%)$ & $0(0 \%)$ & $0(0 \%)$ & $0(0 \%)$ & 4 \\
\hline
\end{tabular}

C virus is an emerging problem. In tertiary care hospital most of the patients of chronic liver disease are in decompensated stage with various complications. HBsAg and Anti-HCV are two important sensitive and cost-effective markers for detection of Hepatitis B and Hepatitis C virus infection. So protection against Hepatitis B and Hepatitis $C$ virus infection should be an important strategy for preventing incidence of chronic liver disease in community.

\section{References}

1. Purcell RH (1993) The discovery of hepatitis virus. Gastroenterology 104: 955 963. Link: https://bit.ly/2RdOT7z

2. Lauer $M$, Walker $D(2001)$ Hepatitis $C$ virus infection (review article) NEJM 345 41. Link: https://bit.ly/2RbrVht

3. Nahar D, Bishwas J, Nahar A (2001) Hepatitis B virus infection in patients with chronic liver disease. Bangladesh Medical J 30: 43-44.

4. Khan M, Kiyosawa K, Yano M (1994) HCV seroprevalence in live disease in Bangladesh (Abstract) ixth biennial scientific meeting, Asian Pacific Association for study of liver, Kulalalampur, Malaysia. Link: https://bit.ly/3ik39rA

5. Alter HJ Seeff LB (2000) Recovery, Persistence and Sequel in Hepatitis C virus infection: a perspective on long term outcome. Smin liver dis 20: 17-35. Link: https://bit.ly/2ZFfv6n

6. Islam N, Khan M (1975) Cirrhosis of liver in Bangladesh (A preliminary report) Bangladesh Med Res Counc Bull 1: 39-44. Link: https://bit.ly/2ZobpPT

7. Islam N, Khan M, Ahmed Z (1981) Cirrhosis of liver. Bangladesh Med Res Counc Bull VII: 45-51.

8. Khan MNI, Sohrabuzzaman APM (1987) Clinical presentations of cirrhosis of liver. Bangladesh Medical J 16: 85-89.

9. Sherlock S, Dooley J (1993) Disease of liver and biliary tract. $9^{\text {th }}$ ed. Oxford: Blackwell scientific publications 643

10. Cortan RS, Kumer V, Collins T (1999) The liver and biliary tract,Robbins pathologic basis of disease. $6^{\text {th }}$ edn. Philadelphia: W.B Saunder $845-901$.

11. Braunwald E, Fauci AS, Kasper DL, Hauser SL, Longo DL, et al. (2001) Disorders of gastrointestinal system. Harrison's principles of internal medicine. $15^{\text {th }}$ edn New York: Mac Graw Hill 2: 1631-1705. Link: https://bit.ly/3bH2e1T

12. Khan M (2004) Hepatitis C virus infection: Recent advances (The Editorial), Bangladesh Medical J 33: 2-3

13. Vrilink H, Reesink HW, Van den Burg PJ (1997) Performances of three genera rations of Anti hepatitis $C$ virus ELISA in donor and patients. Transfusion 37 $845-849$

Citation: Gomes RR, Ali MA (2020) Evaluation of association of demographic profiles and sero prevalence of HBV and HCV among the patients presenting with chronic liver disease and its complications: A Tertiary Care Hospital Based Study. Open J Hepatol 2(1): 001-005. D0I: http://dx.doi.org/10.17352/ojh.000003 
14. Lonry- Cantilena C, Van Randen M, Gibble J, et al. (1996) Routes of infection, viremia and liver disease in blood donor found to have hepatitis $C$ virus infection. NEJM 334: 1691-1696. Link: https://bit.ly/3hjzFZk

15. Khan TS, Rizvi F, Rashid A (2001) Hepatitis C seropositivity among chronic liver disease patients in Hazara, Pakistan. J. of department of Pharmacology and Pathology, Ayub Medical College, Abbottabad, Pakistan 6: 51. Link: https://bit.ly/35oNIQK

16. Chakravarti A, Verma V (2005) Prevalence of hepatitis Cand B viral markers in patients with chronic liver disease: A study from northern India. Indian Journal of Medical Microbiology 23: 273-274. Link: https://bit.ly/33dOV53

17. Blumberg BS, Sutnick AL, London WT (1986) Hepatitis and leukemia: Their relation to Australia antigen. Bull NY Acad Med 44: 1566-1586. Link: https://bit.ly/3m43Ebo

18. Islam MN, Islam KMN, Islam N (1984) Hepatitis B virus infection in Dhaka, Bangladesh. Bangladesh Medical Res Counc Bull X: 1-6. Link: https://bit.ly/2FgKuhz

19. Chowdhury AW (1995) A study of HBsAg status of hospital admitted patients of chronic liver disease and its clinicopathological correlation (Dissertation). Dhaka: BCPS 84-114

20. Uddin J (2001) Clinicopathological correlation of 50 cases of liver biopsy (Dissertation), Dhaka: BCPS. Link: https://bit.ly/3hcKmwZ

21. Boxall EH, Fletwett TH, Paton A, Rassan SW (1976) Hepatitis B surface antigen and cirrhosis in Iraq. Gut 17: 119-121.

22. Hadziyannis S (1974) Chronic viral hepatitis. Clin Gastroenterol 3: 391-408 Link: https://bit.ly/3bLttbi
23. Maynard EP, Sadikali F, Anthony PP, Barker LF (1970) Hepatitis associated antigen and cirrhosis in Uganda. Lancet 1326-1328. Link: https://bit.ly/2DQx1 Ne

24. Kekler SS, Niphadkar KB, Karver SR (1973) Australia antigen in urban endemic hepatitis in Poona. Ind J Med Res 61: 482-485. Link: https://bit.ly/2F701PL

25. Matherws JD, Mackay IR (1970) Australia antigen in chronic hepatitis in Australia. Br Med J 1: 259-261. Link: https://bit.ly/3kfZ4VZ

26. Reed WID, Eddlestan AIWF, Stern RB, Williams R (1973) Detection of HBsAg by radiaoimmuno assay in chronic liver disease and hepatocellular carcinoma in Great Britain. Lancet ii: 690-694.

27. Sobur MA (1988) A clinical study of chronic liver disease (Dissertation), Dhaka: BCPS 126

28. Datta AK (1996) Chronic parenchymal liver disease. Clinical and biochemical imaging and histopathological correlation(Dissertation). Dhaka. BCPS 132133

29. Parveen I (1997) Study of histopathological changes in chronic liver disease in HBsAg positive cases(Dissertation), Dhaka, BCPS 67-88.

30. Maruyama T, AMclachalan, S Lino, K koike, K Kurokawa, DR Mi (1993) The Serology of chronic HBV infection revisited. J Clin Invest 91: 2586-2595. Link: Link: https://bit.ly/35mnDfn

31. Kyi KP, Aye M, Oo KM, Htun MM (2002) Prevalence of Hepatitis C in healtyhy population and patients with liver ailments in Myanmar. Regional Health Forum WHO South- East Asia region 6. Link: https://bit.ly/3kfYli7

32. Rahman MS (2002) Clinico pathological studies of cirrhosis of liver (Dissertation). Dhaka: BCPS
Discover a bigger Impact and Visibility of your article publication with Peertechz Publications

Copyright: ( $) 2020$ Gomes RR, et al. This is an open-access article distributed under the terms of the Creative Commons Attribution License, which permits unrestricted use, distribution, and reproduction in any medium, provided the original author and source are credited.

Citation: Gomes RR, Ali MA (2020) Evaluation of association of demographic profiles and sero prevalence of HBV and HCV among the patients presenting with chronic liver disease and its complications: A Tertiary Care Hospital Based Study. Open J Hepatol 2(1): 001-005. DOI: http://dx.doi.org/10.17352/ojh.000003 